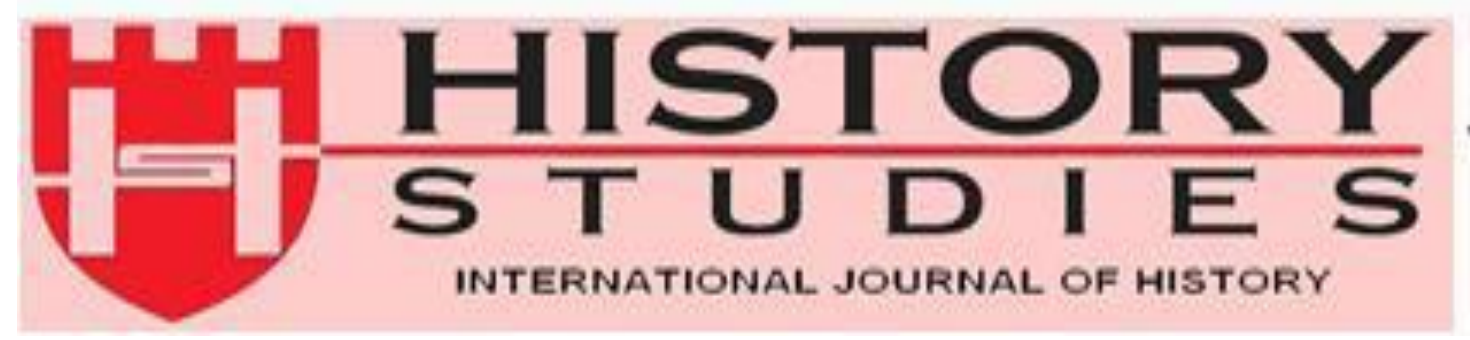

ISSN: 13094173 (Online) 1309 - 4688 (Print)

Volume 8 Issue 2, p. 69-83, June 2016, DOI Number: 10.9738/hişt.2016220342

\title{
Şahruh Dönemi Mâzenderân ve Gilan Seyyidleri (1400-1422)
}

Mazandaran and Gilan Sayyids during the Shahruh Period (1400-1422)

\author{
Yrd. Doç. Dr. Akif RENÇBER \\ Muş Aplarslan Üniversitesi - Muş
}

\begin{abstract}
Öz: Bu makalede Moğol hakimiyeti sonrasinda yerel hanedanlar tarafindan yönetilen Hazar Denizi'nin güneyindeki Mâzenderân bölgesinin Maraşî Seyyidleri'nden Timurlu hakimiyetine geçişi ve sonrasındaki dönem incelenerek özellikle Şahruh döneminde seyyidlerin iç çekişmeleri nedeniyle Şahruh 'un Mâzenderân'ın iç işlerine sıklıkla müdahele ettiği tespit edilmektedir.
\end{abstract}

Anahtar Kelimeler: Şahruh, Seyyidler, Mâzenderân, Gilan, Âmul, Sârî, Timur

Abstract: This article examines the transitional period of the Mazandaran region south of the Caspian Sea from the Marash Sayyids to Tamerlane rule and its aftermath in the Shahruh period. The article presents that because of internal strife among sayyids, Shahruh was able to intervene the domestic affairs of Mazandaran.

Keywords: Shahruh, Sayyids, Tamerlane, Mazandaran, Gilan, Amul, Sari

History Studies Volume 8 Issue 2 June 2016

\section{GİRIŞ}

Şahruh dönemi Mâzenderân Seyyidleri ile alakalı bilgilere giriş yapmadan önce bölgenin coğrafyasını ve kadimden Şahruh dönemine kadar siyasî sergüzeştini kısaca ifade etmek gerekir. 46456 km'lik alanıyla Hazar denizi kıyısında yer alan Mâzenderân, günümüzde Bihşehr, Sârî, Kaimşehr, Babil, Âmul, Nûr, Nûşehr ve Tenkabin şehristanlarından müteşekkildir. ${ }^{1}$ Bölgede, Moğol istilasını müteakip Taberistan isminin yerine Mâzenderân'ın kullanılmaya başlandığını belirtebiliriz. ${ }^{2}$ Bununla beraber isim menşei üzerine de çeşitli tartı̧̧malar vardır. Yoğun ormanlık alanlara ve nemli havaya sahip bir bölge olduğundan Mâzenderân coğrafî̀ konum itibariyle İran'ın diğer bölgelerine nazaran tamamen farklı bir yapıya sahiptir. Bu bölgenin yüksek dağlarla çevrili olması oldukça fazla yağış almasına neden olmaktadır. ${ }^{3} \quad \mathrm{Bu}$ özelliklerinden dolayı kışın ideal bir sıcaklığa sahip olan Mâzenderân, egemen güçlerin kışlak olarak kullandığı bir yerleşim yeri vasfı taşımaktadır. ${ }^{4}$

\footnotetext{
${ }^{1}$ Mustafa Rüstemi, Hüner-i Tabarestan, İntişarat-i Müessese-i Amuzeş Alî-yi Marlik, Babilsor 1392, s. 15.

${ }^{2}$ Guy Le Strange, Serzemin-i Hilafet-i Şarkî, Çev: Mahmud İrfan, Şirket-i İntişarat-1 İlm-u Ferheng, Tahran 1377, s. 394.

${ }^{3}$ Salih Purgari, "Nigahi be Coğrafya-yi Tarih-i Taberistan der Kurun-u Evvel-i Hicri”, ez-Zehra Üniversitesi İnsani Illmler Araştırma ve Illim Dergisi, S. XVII-XVIII, 1380, s. 35.

4 İbn İsfendiyar, Taberistan şehirlerini ikiye ayırarak ormanlı ve ovalık alan şehirleri tasnifi yapar. Ormanlık

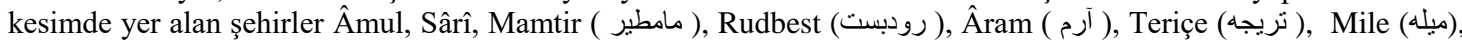

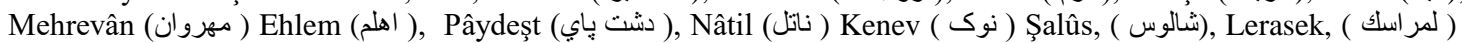

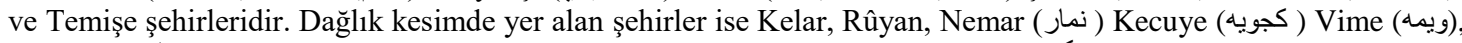

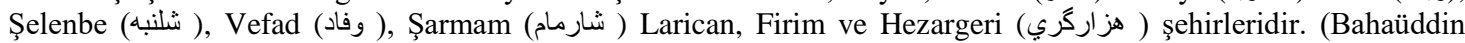
Muhammed b. Hasan İbn İsfendiyar, Tarih-i Taberistan, c. I, Tsh: Abbas İkbal, Tahran 1386, s. 94-95.
} 
Bilinen en eski tarihi kayıtları Hahamenişler dönemine kadar uzanan Mâzenderân bölgesinde ${ }^{5}$ toprakların bir kısmı İslam öncesi dönemde ikta suretiyle kabile reisleri veya mahalli liderlere verilmekteydi. Bunun karşılığında bu kabile reislerinin bazıları, Sâsânîlere asker temininde bulunup ordu masraflarını karşılamaktaydı. Sâsânîlerin zayıf düştükleri dönemlerde Taberistan'da bulunan ikta sahipleri boyunduruk altından kurtulmak için isyan ediyorlardı. Bu sebeple Sâsânîler, Taberistan'a tam anlamıyla hâkim olamıyordu. Bu durum özellikle bölgenin batı kısımlarında daha fazla hissedilmekteydi. ${ }^{6}$

Taberistan, Arap hâkimiyetine geçtikten sonra bölgede bulunan yerel hanedanlar ikta yönetimi seviyesinde Araplara bağlı olarak hayatlarını devam ettirdiler. Araplar, onlara İran'ın Şahin Şahlarından kalma miras hakkını tanımakla beraber karşılığında belli bir miktar haraç ve lüzum olduğunda asker talep etme şartıyla anlaşmaya varmıştı. Belki de bu yarı bağımsız statünün vermiş olduğu imtiyazla ilk dönemde Arap hâkimiyeti Taberistan'da pek te etkili olamadı. Ayrıca burası İran'da Arap tahakkümüne en son giren, dolayısıyla İslamiyet'le en son tanışan İran bölgesiydi. Hicri ikinci asrın ortalarına kadar Taberistan'da basılan sikkelerde Pehlevî hattı bulunuyordu ve halkı hâlâ büyük oranda Zerdüşt dinine inanıyordu. ${ }^{7}$

Taberistan yerel hanedanlarının mütemadiyen sürdürdügü muhalif politikalar, bölgede mevcut otoriteye karşı olan ideolojilerin barınmasına imkân sağlamaktaydı. Bunların en önemlisi bölgenin kaderini birinci derecede etkileyen ve sonraki dönemlerde muhalif duruşun temel dayană̆ olan Şiîliğin bölgeye girişidir. Hz. Ali taraftarı olan Şia mensuplarının Arap liderleri ve Abbasîler tarafından Hicri ikinci ve üçüncü asırda maruz kaldıkları baskılar ve takibatlar onların İran taraflarına göç etmeleri neden oldu. Bunun sonucunda Taberistan ve Deylem bölgelerinde ilk Şia devleti kuruldu. Zeydîler adı verilen bu devlet, 3/9.-4/10. asırlar arasında Taberistan'dan Nişabur'a kadar nispeten geniş bir sahaya hâkim oldular. ${ }^{8}$

Hasan b. Zeyd, Taberistan'da kısa sürede kabul görerek bölge yöneticisi olan Tahirîler karşısında başarı elde etti. Bunun üzerine Abbasi halifesi Müstain, 255/869'da Musa b. Boğa'yı bölgeye gönderdi. Zeydî hareketinin ilerleyişini durdurmak üzere gönderilen ordu, Hasan b. Zeyd karşısında başarı elde edip Taberistan'ın bazı şehirlerini ele geçirdi. Ancak hilafet merkezinde karışıklıkların çıkması, Abbasî ordusunun geri çekilmesine neden oldu. Bu durumdan istifade eden Hasan b. Zeyd, Taberistan bölgesindeki faaliyetlerine devam etti. ${ }^{9}$ Abbasiler, Zeydîlerden bir ara Horasan valisi Rafi b. Herseme aracilığıyla Taberistan'in idaresini aldı. Rafi, 275/889'de Muhammed b. Zeyd'i mağlup ederek Taberistan ve Cürcan'1 ele geçirdi. ${ }^{10}$

Samanîler, egemenlikleri altında olan Horasan'a olası Zeydî saldırısını önlemek maksadıyla, Muhammed b. Harun'u görevlendirdi. Zeydîlere karşı elde edilen başarı üzerine Taberistan valiliğine atanan Harun, kısa bir süre sonra Sâmânîlere isyan edince bölgede

\footnotetext{
${ }^{5}$ Hüseyin Samedî, Ketabnâme-i Mâzenderân, c. I, Sazman-ı Bername-i Ostan-ı Mâzenderân, Sârî 1372, s. 7.

${ }^{6}$ Salih Purgari, agm, s. 42.

7 Seyyid Zahirüddin b. Seyyid Nasirüddin Maraşî, Tarih-i Taberistan Rûyan ve Mâzenderân, Tsh: Muhammed Hüseyin Tesbihi, Müessese-i Matbuat-i Şarki, Tahran 1345, s. 18 (mukaddime); Le Strange, age, s. 394.

8 Abdurrafi Hakikat, Tarih-i Conbiş-i Serbedaran ve Diger Conbişha-yi Iraniyan der Kurun-u Heştom Hicri, İntişarat-1 İlmi, Tahran 1363, s. 98-99.

9 İbnü'l-Esir, el-Kamil fi't-Tarih Tercümesi, Çev: Ahmet Ağırakça vd., c. VI, Hikmet Neşriyat, İstanbul 2008, s. 87-88; İsmail Mehcuri, Tarih-i Mâzenderân, c. I, İntişarat-1 Tus, Tahran 1380, s. 123-128; Adem Apak, Anahatlarlyla İslam Tarihi, c. IV, Ensar Yayınları, İstanbul 2012, s. 302-303; Hasan Kurt, Türk-İslam Dönemine Geçişte Tahiroğulları, Araştırma Yayınları, Ankara 2002, s. 108-109.

10 İbn İsfendiyar, History of Tabaristan, c. II, Çev: Edward G. Browne, Leiden 1905, s. 190-191; Saim Y1lmaz, Mutazıd ve Müktefi Döneminde Abbasiler, Kayıhan Yayınları, İstanbul 2006, s. 100.
} 
yeniden bir asayiş sorunu baş gösterdi. Ayrıca Deylemlilerin de bu süreçte bir isyanı vuku buldu ancak başarıya ulaşmadı. ${ }^{11}$

Esfar b. Şireveyh, Zeydîlerin son imamı Hasan b. Kasım'1 316/928'de öldürünce Taberistan, Deylemlilerin hâkimiyeti altına girmiştir. Bir süre sonra Esfar'ın komutanlarından olan yine bir diğer Deylem asıllı Merdaviç b. Ziyar ile Kazvin'de yaşananlardan dolayı arası açılmıştır. Komutanların Merdaviç’ten yana tavır koyması ve Esfar'ın zulmünden kurtulmak istemeleri üzerine Esfar, Merdaviç tarafından öldürülmüş ve Taberistan'ın yeni hâkimi olmuştur. ${ }^{12}$ Bundan sonra Taberistan, Selçukluların idaresine girene dek Büveyhîler, Sâmânîler ve Ziyarîler arasındaki savaşlarda sürekli el değiştirdi. Taberistan, 360/971'de Ziyarîlerin idaresine girdikten sonra 370/981'de Büveyhî lideri Adudüddevle tarafından ele geçirildi. ${ }^{13}$

Selçuklu Devleti kurulduktan sonra yaşanan hızlı fetih hareketleriyle Taberistan'a kadar ulaşı1mış, bu bağlamda Tuğrul Bey, Kutalmış'a Taberistan'ın fetih icazetini ve bölgenin idaresini tevdi etmiştir. ${ }^{14}$ 606/1209-1210 y1lında Mâzenderân'da yaşanan karışıklıklardan istifadeyle Alâeddin Muhammed savaş yapmaksızın Mâzenderân'ı kolayca ele geçirdi. ${ }^{15}$ Fakat Mâzenderân'da Harezmşah Devleti'nin idaresi yaklaşık on yıl sürdü. Otrar olayı ile Harezmşah Alaaddin Muhammed'in peşinden Mâzenderân'a giren Moğollar, bölgeyi idareleri altına aldılar. Bir süre sonra yerel hanedanlardan Bavendîlerin Kinhariyye soyu, onlar adına bölgeyi yönetmeye başladılar. $735 / 1335$ 'de Ebu Said'in ölümüyle İran coğrafyasında zayıflayan İlhanların yerine birçok yerel hanedan zuhur etti. Bavendiler ile beraber bölgede bir süre sonra ortaya çıkan Maraşîler 760/1359'dan Timur'un bölgeye gelişine kadar (794/1392) Mâzenderân'da hüküm sürdüler. İran coğrafyasında yer alan irili ufaklı birçok yerel hanedanı itaat altına almaya başlayan Timur, batı istikametinde Mâzenderân'a ulaştığında öncelikle

History Studies

Volume 8 Issue 2 bölgenin doğusunda yer alan Cürcan ve Esterabad hâkimi Emir Veli'yi ortadan kaldırmış, ardından da Mâzenderân'ın merkezinde hüküm süren Maraşî hanedanı ile girdiği mücadelede bölgeyi ele geçirmiştir. Ayrıca Maraşîler bölgeden sürgün edilmiştir. ${ }^{16}$

Timur, Mâzenderân'ı ele geçirdikten sonra Âmul'un yönetimini İskender Şeyhî’ye verdi. Fakat İskender Şeyhi ilk firsatta isyan ederek bölgenin dağlik kesimlerini (Firuzkuh) karargâh edindi. Emir Süleyman Şah komutasında üzerine gelen Timur ordusuna karşı emirlerinden Kiya Hüseyin'i üç yüz kişilik bir grupla Âmul-Çalus yolunu kapamakla görevlendirdi. Firuzkuh kalesi müstahkem bir kale olmasına rağmen Firuzkuh’tan ayrılıp Nûr şehrine hareket etti. Şehrin idaresi elinde olan Pâdüspânî lideri ile arası iyi olmadığından yakalanıp Timur'a teslim edilecekti. Ancak İskender, hileyle kaçmayı başardı. 806/1404'de bizzat Timur'un bölgeye gelişiyle kısa bir süre sonra ele geçirilip öldürüldü. İskender'in ele geçirilmesi için sefere çıan Timur'un yanında Seyyid Kemalüddin'in oğulları Seyyid Ali ve Seyyid Gıyasüddin'de bulunuyordu. ${ }^{17}$ Timur, ömrünün sonlarına doğru Âmul'u Gıyaseddin adlı

\footnotetext{
${ }^{11}$ İbnü'l-Esir, age, c. VI, s. 348-357; Y1lmaz, age, s. 288-289.

12 İbnü'l-Esir, age, c. VI, s. 523; İbn İsfendiyar, age, c. I, s. 317; İsmail Mehcuri, age, c. I, s. 167-169; Akif Rençber, "İslam Fethinden Irak Selçuklularının Yıkılışına Kadar Kazvin'in Siyasî Tarihi”, Insan ve Toplum Bilimleri Araştırmaları Dergisi, C. I, S. I, 2012, s. 235.

${ }^{13}$ Osman Gazi Özgüdenli, “Taberistan”, TDVİA, c. XXXIX, İstanbul 2010, s. 322.

${ }^{14}$ Reşidüddin Fazlullah, Camiü't-Tevarih Selçuklu Devleti, Çev: Erkan Göksü-Hüseyin Güneş, Selenge Yayınları, İstanbul 2010, s. 105.

${ }^{15}$ Alaaddin Ata Melik Cüveynî, Tarih-i Cihangüşa, c. II, Çev: Mürsel Öztürk, Kültür Bakanlığı Yayınları, Ankara 1988, s. 57-58; Hamdullah Müstevfî, Tarih-i Güzide, Tsh: Abdü'l-Hüseyin Nevaî, Emir Kebir, Tahran 1364, s. 490; Bertold Spuler, Iran Moğolları, Çev: Cemal Köprülü, TTK Yayınları, Ankara 2011, s. 37.

16 Akif Rençber, Mâzenderân (Taberistan) Tarihi 1220-1392, (Firat Üniversitesi Sosyal Bilimler Enstitüsü, Yayınlanmamış Doktora Tezi), Elazı̆̆ 2015, s. 34-97; Nizamüddin Şami, Zafername, Çev: Necati Lugal, TTK Yayınları, Ankara 1987, s. 156-157.

${ }^{17}$ Erdeşir Borzger, Tarih-i Taberistan, Tsh: Muhammed Şükrî Fûmeşî, Neşr-i Resaneş, Tahran 1388, s. 570-573.
} 
kardeşiyle birlikte Maraşî hanedanın kurucusu olan Seyyid Kıvamüddin'in torunu Seyyid Ali'ye verdi. Bununla birlikte bölgenin başkenti olan Sârî'de Timurlu yönetici bulunmaktayd1. ${ }^{18}$

\section{Sürgündeki Maraşîlerin Mâzenderân’a Geri Dönmesi}

Timur, hükümdarlık topraklarını oğulları arasında dörde bölmek suretiyle taksim etmişti. Buna göre; Miranşah ve oğulları Azerbaycan eyaletinde, Ömer Şeyh ve oğulları Orta ve Güney İran'da, Cihangir ve oğulları Kabil bölgesinde, Şahruh ve oğulları ise Horasan ve Mâzenderân'da yönetimi uhdelerine aldırlar. Ancak bu parçalı siyasî yapıya kısa bir süre sonra müdahale eden Şahruh, savaş ve diplomasi yoluyla babasının hükmettiği toprakların neredeyse tamamını 822/1419'da ele geçirdi. Bu topraklar arasında ona daha önce verilen Mâzenderân'da bulunuyordu. Onun Timurlu topraklarının çok büyük bir kısmına hâkim olmasıyla hanedan, eyalet ve yerel güçlerden oluşan sayısız iktidar merkezini dengede tutması sorunu karşısına çıktı. ${ }^{19} \mathrm{Bu}$ yerel hanedanlardan biri, yerel halk nazarında muteber olan Maraşîler idi.

$\mathrm{Bu}$ arada Timurlu şehzade veya mirzalarının iktidar çekişmelerinde Mâzenderân'ın dolaylı ya da doğrudan ilgisinin bulunduğunu söylemek mümkündür. Bu bölgeye hükmeden şehzade veya mirzalar bu kavgaların hep içinde yer almışlardır. Bu bağlamda Timurlularda yaşanan iktidar mücadelelerinde kaybeden taraf Mâzenderân'a sığınıyordu. Bu duruma Said Hoca karşısında yenilen Sultan Ali Sebzvârî’nin Mâzenderân'a kaçması örnek verilebilir. ${ }^{20}$

Maraşîler'in sadece bir kısmı Timur'un sağlığında Mâzenderân'a geri dönebilmişti. Geri kalanlar onun ölümünden sonra Şahruh'un huzuruna vararak ondan bölgeye geri dönmeyi talep ettiler. Şahruh, onların bu taleplerini yerinde bularak Mâzenderân'a geri dönmelerini uygun buldu. Bu arada Seyyid Kıvamüddin 801/1398 y1lında sürgünde olduğu Kaşgar'da vefat etmişti. Diğer kardeşleri Seyyid Rızaüddin ve Seyyid Fahrüddin de ölmüşlerdi. Seyyidlerden bir grup Herat'ta bulunan Şahruh'un huzuruna vararak Timur'un Âmul şehrini Seyyid Ali'ye tevdi ettiğini, kendilerinin de bölgeye gitmelerini talep ettiklerini söylediler. Bununla beraber şayet Mâzenderân'a geri dönerlerse burada Timurluların haklarını koruyacaklarını ve devletin payidar kalması için dua edeceklerini belirttiler. Bunun üzerine Şahruh, onlara Sârî ve Âmul şehirlerini verdiğini beyan etti. ${ }^{21}$ Şahruh, Maraşî Seyyidlerini oldukça fazla önemsemekteydi. Çünkü onlar batıya giden yolun hemen kuzeyinde stratejik bir konumda yer alıyorlardı. Ayrıca Maraşîler, ipek üreticisi zengin bir bölgeyi denetim altında tutuyorlardı. ${ }^{22}$ Sürgünde bulunan Maraşîlerin Mâzenderân'a geri dönmesine Şahruh'un onay vermesinin bir başka nedeni kanaatimizce bölgede yaşanacak iç çekişmelerin Timurluları bu anlamda rahatlatacak olmasıdır. Zira zıt iki merkezli bir idarenin varlığı, bölgede iç çekişmelerin yaşanmasına ve merkeze karşı itaat sınırları dâhilinde bağlı kalmalarına imkân tanıyabilirdi. Nitekim Seyyid Rızaüddin'in soyundan gelen Maraşîlerin bölgeye gidişi sonrası Seyyid Kemalüddin'in oğlu Seyyid Ali ile diğer Maraşîler arasında uzun yıllar sürecek çatışmanın fitili ateşlendi. Seyyidlerin bölgeye dönmesinden önce yaşanan isyanlar merkezi idareyi oldukça fazla uğraştırmıştı. Bu sorunun çözümü bölge halkı tarafindan oldukça sevilen Seyyidler ile sağlanabilirdi. Onlar bir yandan kendi iç çekişmeleri ile uğraşıp güçlerini tüketirken bir yandan da Şahruh'un iltifatına mazhar olarak bölgede idareyi tamamen ele geçirmenin hesaplarını yapabilirlerdi.

\footnotetext{
${ }_{18}$ Beatrice Forbez Manz, Timurlu İran'ında İktidar, Siyaset ve Din, Çev: Dilek Şendil, Türkiye İş Bankası Kültür Yayınları, İstanbul 2013, s. 166.

19 Age, s. 17-19; Faruk Sümer, Karakoyunlular, c. I, TTK Yayınları, Ankara 1992, s. 104.

${ }^{20}$ İsmail Aka, Mirza Şahruh ve Zamanı, TTK Yayınları, Ankara 1994, s. 63.

${ }^{21}$ Marașî, age, s. 245.

${ }^{22}$ Manz, age, s. 164.
} 
Seyyidler topluluğu Esterâbâd'a vardığı sirada Sârı’deki Timurlu valisi Şemseddin Gurî’nin yönlendirmesiyle Toga Timurlu bakiyesi Pir Padişah, Seyyidlere engel olup, onları esir aldı. Aynı zamanda paralarına el koydu. Bu haber Sârî’ye ulaştığında halk arasında infial meydana geldi. Şemseddin Gurî’ye karşı ayaklanan Sârî halkı, onu öldürdü. Bunlar daha sonra Esterâbâd'a doğru yola koyuldular. Onlara Âmul halkı da iştirak etti. Ayaklanan bu halk topluluğu öncelikle Âmul'de bulunan Seyyid Ali'ye müracaat etmiş ancak yanıt alamamışlardı. Daha sonra kararlı bir şekilde Pir Padişah'ın üzerine doğru Seyyidleri kurtarmak için yollarına devam ettiler. Zira onlar daha önce Mâhâneser savaşında ${ }^{23}$ olduğu gibi Seyyidlere bir zarar gelmesini istemiyorlardı. Dervişlerin bu ayaklanması karşısında Pir Padişah da kayıtsız kalmadı ve Seyyidleri derhal serbest bıraktı. Mâzenderân halkının Seyyidlere duyduğu teveccühün ne denli büyük olduğunu bu olay özelinde ifade etmek mümkündür. Büyük bir halk ayaklanması örneği sergileyen Seyyid taraftarları, (dervişler) bölge siyasî hayatına bu müdahaleyle birinci derecede tesir etmişlerdir. Serbest kalan Seyyidler, Âmul'e gelerek amcazâdeleri Seyyid Ali'ye hitaben ataları Seyyid Kıvamüddin'in yaptığı taksimata uymasını talep ettiler. Buna göre Âmul'un Rızaüddin'in çocukları olarak kendilerine ait olduğunu belirttiler. Bu taksimata göre Seyyid Ali, Sârî’ye gitmeliydi. ${ }^{24}$

Seyyid Rızaüddin'in bakiyeleri ve dervişler, Seyyid Ali'ye dinen sulh yapmanın gerekli olduğunu söylemiş, Seyyid Ali ise onlara bu hususta zorluk çıkarmayacağını ancak Şahruh'a başvurulması onun onayının alınması gerekliliğine vurgu yapmıştı. Zira Şahruh'un valisi olan Şemseddin Gurî, Seyyid taraftarları tarafından öldürülmüştü. $\mathrm{Bu}$ keyfiyetin cezasız kalmayacağı düşüncesiyle Seyyid Ali, Şahruh'un onayını alma ihtiyacı hissetmiştir. Ayrıca Seyyid Ali, bu davranışıyla Şahruh'un onayını almaksınız hareket etmediğini özellikle belirterek onun desteğini sağlamayı amaç edinmiş olabilir. Şahruh'a gönderilen elçi huzura vardığında durumu bildirmiş, buna karşılık Şahruh, Âmul ve Sârî’yi seyyidlere verdiğini söylemişti. Bunun üzerine daha önce Mir Kıvamüddin'in yaptığı taksimat gereği Âmul, Seyyid Rızaüddin'in bakiyelerine verildi. Âmul'de Timurlular adına yönetici olan Seyyid Ali ise Sârî’ye gitmek zorunda kaldı. Sârî’ye geri dönen Seyyid Ali, diğer kardeşi Seyyid Gıyasüddin'e babaları Rızaüddin'in yaptığı taksimat gereği Barfuruş'ta bazı köyler hariç ona verdiğini hatırlatarak Gıyasüddin'i yanından uzaklaştırmaya çalıştı. Bu girişimi sayesinde Gıyasüddin, Barfuruş'ta ikamet etmeye mecbur kald1. ${ }^{25}$ Çoklu siyasî güç odaklarının varlığ 1 , Seyyidlerin iç meselesinde oldukça karmaşık bir durum ortaya koymaktaydı. Şahruh dönemi Mâzenderân'da Seyyidlerin iç çekişmelerinin başlangıcını oluşturan bu olay, dinî meşruiyet temelli yaklaşımın bir tezahürü olarak cereyan edecektir. Bölge içinde üç kutuplu bir yapılanma varken, bölge dışında Şahruh gerçeği söz konusudur. Bu konunun biricik kaynağı olan Zahirüddin Maraşînin "Tarih-i Taberistan Rûyan ve Mâzenderân” adlı eseri daha çok seyyidlerin bölgedeki politikaları ve siyasî manevralarına yönelik bir anlatım gerçekleştirmiştir. Timurlu kaynaklarında ise bölgedeki olaylar, sadece merkezi ilgilendirdiği kadarıyla ve sığ bir düzlemde kayda geçirilmiştir.

Maraşîlerin Mâzenderân'a geri dönüş süreci gerçekleşirken öte taraftan bölgeye sığınan isyanc1 grupların bertaraf edilmesi için Şahruh gevşek davranmiyordu. Bu bağlamda Mâzenderân'da hüküm süren Pir Padişah'ın, Şahruh'a isyan edip kendisine sığınan Said Hoca'yı himaye etmesi, sonrasında ise onun teslim edilmesi için Şahruh tarafından gönderilen elçinin eli boş gönderilmesi, Şahruh'un bölgeye müdahale etmesi sonucunu doğurdu.

\footnotetext{
${ }^{23}$ Bu savaş, Maraşi Seyyidleri ile Timur arasında 26 Zilkade 794/14 Ekim 1392 tarihinde yapılmıştır. Savaş birkaç gün boyunca devam etmiş nihayetinde Timur kuvvetlerinin galibiyeti ile sonuçlanmıştır. Maraşiler bu savaş ile Mâzenderân hâkimiyetini kaybetmiştir. Akif Rençber, agt, s. 98-102.

${ }^{24}$ Maraşî, age, s. 246.

${ }^{25}$ Age, s. 247- 248.
} 
Esterâbâd'a yürüyen Şahruh, Sultan Duvin mevkiinde yapılan savaşı kazanarak Mâzenderân'da isyan halinde olan asileri dağıtmış oldu. Bundan sonra Mâzenderân'ın yönetimi 808/1406'da Ömer Mirza'ya verildi. ${ }^{26}$ Ancak çok geçmeden Ömer Mirza, Şahruh'a başkaldırdı. Ömer Mirza'nın ayaklanması bastırıldıktan sonra 809/1407'de Mâzenderân'ın idaresi Uluğ Bey'e tevdi edildi. ${ }^{27}$

Mâzenderân'da yaşanan isyan hareketleri, hükümdarlığının başlarında Şahruh'un mesaisinin önemli bir kısmını işgal etmiş olmalıdır. Zira 808/1406'dan 810/1408'e üç kez bölgede yöneticilerin itaatsizliği ya da bölgede ortaya çıkardıkları sorunlar sebebiyle Şahruh, bizzat Mâzenderân'a müdahale etme gereksinimi duymuştu. Bunlardan biri 18 Cemaziyelahir 810/20 Kasım 1407'de gerçekleşmiştir. Şahruh, Belh'ten Herat'a döndüğü sırada sâbık Mâzenderân hâkimi Pir Padişah'ın bölgeye doğru hareket ettiği haberini almıştı. Pir Padişah'ın Esterabâd'1 kuşatmasıyla Şahruh harekete geçti. Mâzenderân yöneticisi Uluğ Bey, Şahruh gelmezden evvel Pir Padişah'in üzerine yürüyerek onu Rüstemdar'a kaçmaya mecbur etti. Buna rağmen Şahruh, Esterabâd'a giderek şehrin imar edilmesi talimatını verdi. Şahruh, Mâzenderân'ın yöneticisinin Uluğ Bey olduğunu bir kez daha teyit ederek kışı burada geçirdi. $\mathrm{Bu}$ arada Rüstemdar'a kaçan Pir Padişah, buranın lideri Padüspanî hanedanına mensup Keyumers b. Bisutun'a sı̆̆ınmıştı. ${ }^{28}$

\section{Sârî’de Seyyid Ali Sârûyî’nin İdaresi ve Âmul Seyyidleri İle Mücadele}

Seyyid Ali Sârûyî, Sârî’ye döndükten kısa bir süre sonra Âmul'de Rızadüddin'in bakiyeleri arasında liderlik krizi ortaya çıktı. Âmul ileri gelenleri ve dervişler, Seyyid Raziyüddin'den memnun değillerdi. Seyyid Ali Sârûyî meseleye müdahil olarak; vaktiyle Gilan'a giden Seyyid Muhammed'in oğlu Seyyid Abdülmuttalib'in Âmul'de lider olması fikrini ileri sürdü. Ancak Seyyid Abdülmuttalib'e yapılan teklif olumsuz karş1lık buldu. Dervişler kriz ortamının aşılamamış olması dolayısıyla alternatif arayışlar içinde Seyyid Ali Sârûyî'nin kapısını çaldılar. Dervişler, kendi aralarında oluşturdukları bir heyet ile onunla sözlü bir akit yaptılar. Âmul dervişlerinden bir gurubun muhalifliğine rağmen Seyyid Ali Sârûyî, Âmul'de idareyi tekrar uhdesine almayı başardı. ${ }^{29}$

Sârî ve Âmul seyyidleri yani Maraşîler, kendi iç çekişmelerinin yanı sıra o dönemde güçlü olan ve hem Mâzenderân hem de civar bölgelerde siyasî olaylara müdahale eden Rüstemdar meliki Melik Keyumers ile de mücadele içindeydiler. Melik Keyumers, zaman zaman Âmul seyyidleri tarafında, zaman zaman ise Sârî seyyidleri tarafında yer alarak Mâzenderân işlerine müdahil olma firsatı edinmekteydi. Nitekim bu firsatlardan biri Seyyid Ali Sârûyî’ye karşı üçlü bir ittifak oluşumuydu. Bu sırada ittifak içinde olan Gilan ve Mâzenderân seyyidlerini birbirine düşürüp zayıflatmanın yollarını arayan Melik Keyumers, Seyyid Ali Sârûyî'ye karşı kardeşi Seyyid Gıyasüddin'in yanı sıra Seyyid Ali Âmulî ile bir üçlü ittifak gerçekleştirdi. Buna göre Sârî'de yönetime Seyyid Ali Âmul'nin kardeşi Seyyid Murtaza geçecekti. Bu ittifak ile yetinmeyen Melik Keyumers, Rey'de bulunan Timurlu valisine de yardım etmesi talebinde bulunmuştu. Galip gelmeleri halinde onun hizmetine gireceklerini vaat etmişlerdi. Müttefikler, Seyyid Ali Sârûyî yi yerinden etmeyi başararak Herat'a kaçmaya mecbur ettiler. Bu arada Seyyid Ali Sârûyî'ye sadık kalan Zahirüddin

\footnotetext{
${ }^{26}$ Kemaleddin Abdurrezzak Semerkandî, Matlaü'Sadeyn ve Mecmaü’l-Bahreyn, c. III, Pejuheşgahî Ulum-u İnsanî ve Mütalaat-1 Ferhengî, Tahran 2004, s. 56-59; Aka, age, s. 72.

${ }^{27}$ Tacü’s-Selmanî, Tarihname, (çev. İsmail Aka), TTK Yayınları, Ankara 1999, s. 77.

${ }^{28}$ Tacü's-Selmanî, age, s. 88-89; Aka, age, s. 76.

${ }^{29}$ Maraşî, age, s. 248-251.
} 
Maraşînnin babası Nasîrüddîn, Şahruh'tan yardım talep edilmesi fikrini ortaya atmış, bu yardımın vergi verilerek sağlanılması gerekliliğine vurgu yapmıştı. ${ }^{30}$

Seyyid Rızaüddin'in torunu, aynı zamanda Seyyid Ali Âmulî’nin kardeşi Murtaza, kısa süreliğine Sârî'de Seyyid Rızaüddin'in bakiyeleri adına yönetimi üstlendi. Ancak onun sorumsuz davranışları Sârî halkını rahatsız etmekteydi. Bu arada yukarıda belirttiğimiz gibi Şahruh'tan vergi verme karşılığında yardım sağlanması fikri, hayata geçirilmiş ve bu sayede Mâzenderân'a geri dönebilen Seyyid Ali Sârûyî, kan dökülmeden Sârî’de yönetimi bir kez daha uhdesine almayı başarmıştır. ${ }^{31}$

812/1409-1410 yılında Murtaza'nın Sârî'den uzaklaştırılmasıyla vergi verme sorunu ortaya çıktı. Zira Zahirüddin Maraşî’nin belirttiğine göre uzun mücadele dönemi nedeniyle bozulan iktisadî düzen vaat edilen verginin ödenmesini zorlaştırmaktaydı. Bu sebeple Şahruh'un huzuruna Herat'a Seyyid Ali Sârûyî'nin kardeşi Nasîrüddin, ricacı olmak üzere yolland1. Söz verilen verginin iki ya da üç yıl sonra ödenebileceğinin ifade edilmesine oldukça hiddetlenen Şahruh, Nasîrüddîn'e babası Timur döneminde Mahaneser kalesinde ele geçen zenginliklerin tekrar kaleye gömüldügünü, bu hazinenin oldukça fazla olduğunu dolayısıyla böylesi bir bahanenin geçerli olmadığını söyledi. Bu ithamlar karşısında zor durumda kalan Nasîrüddîn, mezkûr soruların Seyyid Ali Sârûyî’ye sorulası gerektiği cevabını verdi. Bunun üzerine Sârî̀ye, Şahruh tarafından bir elçi yollandı. Şahruh'un elçisi Seyyid Ali Sârûyî tarafından diplomatik kurallara aykırı olarak karşılandı. Saçları tıraş edilen elçi geri gönderildi. Savaş sebebi sayılan elçiye kötü muamele, 816/1414 yılında Şahruh'un bölgeye ordu sevk etmesiyle karşılık buldu. Ancak Şahruh'un bizzat bulunduğu ordu, Semerkant'a yapılan bir saldırı haberi ile geri döndü. Bu olay sonrası Nasîrüddîn'in girişimleriyle, Seyyid Ali Sârûyî,

History Studies Volume 8 Issue 2 June 2016 oğlu Murtaza'yı muhtelif hediyeler ile Şahruh'a yollayıp özür diledi. Özrü kabul edilen Sârûyî, eski statüde Mâzenderân'da idaresini sürdürdü. ${ }^{32}$ Böylece ikinci kez seyyidlerin merkezi yönetime karşı itaatsizliklerine ciddi bir karşıllk verilmemiş oldu.

Mâzenderân'da iç çekişmeler bağlamında bunlar yaşanırken Şahruh, 817/1415'de Mâzenderân, Cürcan ve Esterabâd'ı Horasan bölgesiyle beraber oğlu Mirza Baysungur'a tevfiz etti. ${ }^{33}$

Bu arada Seyyid Ali Sârûyî'nin Nikris hastalığından muzdarip olması Gilan'da bulunan Seyyid Ali Âmulî’yi Âmul'e geri dönme konusunda ümitlendirmişti. Bu sebeple Seyyid Ali Âmulî, Seyyid Ali Sârûyî’nin ölümünden kısa bir süre önce elli kadar sadık adamıla Âmul'e döndü. Âmul dervişlerinin ileri gelenleri, Giyasüddin ile bir toplantı yaptılar ve Sârûyı̂’nin durumunu öne sürerek Seyyid Ali Âmulî'nin Âmul'e yönetici olması gerektiğini belirttiler. Bu arada 820/1418 yılında hastalığı iyice artan Sârûyî, kardeşi Gıyasüddin'i yanına çağırarak ona vasiyetini bildirmek istedi. Ancak o huzura geldiğinde yeğeni Murtaza'nın babasının tahtına oturduğunu görüp ordugâhına geri döndü. Kısa bir süre sonra ise abisi Sârûyî’ye Murtaza'nın lider olması fikrinin doğru olmadığı yönünde bir mektup gönderdi. Bunun üzerine Sârûyî'nin bir başka kardeşi Nasîrüddîn, olaya müdahil olarak Gıyasüddin'e bu karara saygı duyması gerektiğini bildiren bir haber yolladi. ${ }^{34}$

${ }^{30}$ Age, s. 252-260.

${ }^{31}$ Age, s. 260.

${ }^{32}$ Age, s. 261-262.

${ }^{33}$ Semerkandî, age, c. III, s. 183; Aka, age, s. 108.

${ }^{34}$ Maraşî, Age, s. 263-266. 


\section{Seyyid Murtaza'nın Sârî Hükümdarlığı ve Amcası Nasîrüddîn ile Mücadelesi}

820/1418 yılında Seyyid Ali Sârûyî vefat edince Nasîrüddîn, yeğeni Murtaza'nın hamisi konumunda hareket etti. Bu bağlamda onun adına Mâzenderân'da biatler almaya başladı. Bu arada Rüstemdar meliki Keyumers ile bir anlaşma yapılmıştı. Yapılan anlaşma gereği Melik Keyumers'in kızı ile Murtaza evlendirildi. Bunun yanı sıra Mâzenderân'ın dağlık topraklarının bir kısmı ve Larican'ın yönetimi Keyumers'e verildi. ${ }^{35}$ Muhtemelen bu anlaşma ile Keyumers'in, Seyyidlerin toprak bütünlüğ̈̈ne müdahale etmemesi ve onlara karş1 herhangi bir ittifak içinde bulunmaması karşılığında gerçekleşmişti.

Bunun yanı sıra Seyyid Nasîrüddîn, yeğeni Murtaza adına aldığı biatler sonrası hâkim güç olan Şahruh'a bu taht değişikliğinin resmiyet kazanması için bir heyet gönderdi. Ancak elçiler, daha önce verilen vergi sözünün Şahruh tarafından dillendirilmesi cevabı ile karşı karşıya kaldılar. Şahruh, vergi verilemez ise bu değişikliğin tanınmayacağını elçilere açıkça ifade etti. ${ }^{36}$ Ancak bölgeye kendisine haber verilmeksizin yapılan bu değişiklik sonrası Seyyidleri tedip amaçlı bir sefer yapıldığına dair bir bilgi bulunmamaktadır. Zahirüddin Maraşî’nin ifade ettiğine göre; Şahruh, bölgede yaşanan iktidar mücadelelerine müdahale etmeyi pek düşünmemektedir. Ancak Seyyidlerin kendi iç çekişmelerinde bizzat Şahruh veya onun valilerinden talep edilen yardımlar sonrası müdahil olma söz konusudur. Bu müdahil olma meselesi de şarta tabi olarak gerçekleşmektedir. Vergi verme şartı koşularak seyyidlerin yardım taleplerine olumlu cevap verilmiştir. Tabiiyetin bir esası olan verginin, tabi-metbu ilişkisinde başlangıçta devre dışı bırakıldığını görmekteyiz. Daha sonra iç çekişmelerden kaynaklı bunun bir koz olarak Şahruh tarafından kullanıldığını belirtebiliriz. Ancak vergi vermeyen Mâzenderân Seyyidlerine Şahruh'un ciddi bir müdahalesinin olmaması dikkate şayandır.

821/1419 yılı sonlarında Nasîrüddîn ile Murtaza arasında ihtilaflar ortaya çıkmaya başladı. Zahirüddin Maraşî’nin belirttiğine göre bu ihtilafın sebebi İskender Ruzefzun adında bir Nöker idi. İskender, Nasîrüddîn'den ayrılarak Murtaza'nın hizmetine girince Murtaza, bu durumu kabul etmedi ve onu Nasîrüddîn'e geri yolladı. Onun amca yeğen arasında koğuculuk yapmak suretiyle ihtilafa yol açması sonucu gerginlik giderek büyüdü ve ikilinin birbirlerine ağır sözler sarf etmesi sonucunu doğurdu. Nihayet Nasîrüddîn ile Murtaza arasındaki gerginlik savaş yapacak seviyeye kadar ulaşt. ${ }^{37}$

Safer 822 / Şubat 1419'da Seyyid Murtaza, amcası Seyyid Nasîrüddîn ile savaş yapmak üzere ordusuyla Bazargah'a doğru yola koyuldu. Meydana gelen savaşta her iki taraftan da oldukça fazla kayıplar oldu. Savaşı Seyyid Murtaza kazandı ve Seyyid Nasîrüddîn tekrar toparlanmak üzere Barfuruş'a geldi. Ancak Murtaza onun toparlanmasına firsat vermeden üzerine saldırdı. Bavil nehri kenarında bir kez daha gerçekleşen savaşı Murtaza yine kazandı. Nasîrüddîn bu yenilgi sonrası Âmul'e giderek burada bulunan Seyyid Ali Âmulî’ye ittifak teklifinde bulundu. Ancak olumsuz cevap alınca Şahruh'tan yardım talep etmek üzere Herat'a doğru yola koyuldu. Şahruh'un yardımına mazhar olabilmek için Nasîrüddîn bir kez daha vergi verme talebinde bulundu. Buna göre; her yıl Esterabad ölçüsü esas alınarak 40 Hervâr $^{38}$

\footnotetext{
35 Keyumers'e verilen topraklar; Nemarustak ( نما روستاق), Dilarustak (ديلا روستاق) ve Teriterustak ( تريته روستاق) kasabalarıdır. Maraşî, age, s. 268.

${ }^{36}$ Maraşî, Age, s. 268.

${ }^{37}$ Age, s. 269-271.

${ }^{38}$ Ortaçağın yaygın ölçü birimlerinden biri olan Hervâr'ın genellikle Menn hesabına dönüştürülerek kullanıldığı bilinmektedir. Menn ölçü biriminin ise bir standardı yoktu. Walther Hınz'ın İslam'da Ölçü Sistemleri kitabında İran'ın kuzeyinde kullanılan Menn'in bir biriminin 1,92 kg'a tekabül ettiği ifade edilmektedir. Walther Hınz, İslam 'da Ölçü Sistemleri, (çev. Acar Sevim), Edebiyat Fakültesi Yayınları, İstanbul 1990, s. 17-23. Bu durumda kg hesabıyla bu miktar, yıllık yaklaşık 3 ton ibrişime denk gelmektedir. Ayrıca devlet ümerasına verilmesi taahhüt
} 
kırmızı ve beyaz ibrişim Herat'a vergi olarak verilecekti. (Her Hervâr 40 Menn yapar) bundan başka 10 Hervâr da devlet ümerasına verme vaadinde bulunan Nasîrüddîn, Şahruh'tan yardım sözünü almayı başardı. Timurlu emirlerinden Emir Firuzşah, Nasîrüddîn ile Mâzenderân'a gitmek üzere harekete geçti. Emir Firuzşah, Damgan'a ulaştığında bu ittifaktan haberdar olan Seyyid Murtaza derhal oğlu Muhammed'i onun huzuruna yollayarak Nasîrüddîn'in vaat ettiği verginin 10 Hervâr daha fazlasını vermeyi taahhüt etti. Aynı zamanda bu ittifaktan ayrılması ve kendilerine destek vermeleri halinde onun ordusunun ulufesini de karşılama sözü verildi. ${ }^{39}$

Emir Firuzşah, Seyyid Nasîrüddîn'i yanına çağırarak Murtaza'nın kendisine yaptığı tekliften bahsedince Nasîrüddîn, "Ey Emir bugüne kadar onlar Hazine-yi Amireye bir miskal ibrişim vermediler. Benim gelmemden dolayı geldiler. Bize süre ver düşünelim” dedi. Emir Firuzşah ise ona yaptığı hatalardan ${ }^{40}$ dolayı başına bunların geldiğini söyleyince Nasîrüddîn otağına geri dönerek nökerleri ile bir toplantı yaptı. Burada alınan karar gereği Firuzşah'a bir mektup yolladı. Mektuba göre; Nasîrüddîn, Murtaza ile sulh yapacağını belirtmekteydi. ${ }^{41}$

Nasîrüddîn, mücadeleden vazgeçmeyerek yeni ittifak arayışına devam etti. Bu sebeple o, Sevadkuh'a gelerek Melik Keyumers'den Murtaza ile mücadelesinde yardım istedi. Yardım talebini kabul eden Keyumers, onun Lapur'a gelmesini, savaşın burada yapılmasının münasip olduğunu belirtti. Öte taraftan Murtaza ise bu ittifaktan haberdar olunca Seyyid Ali Amulî'den yardım istedi. Lapur'da Seyyid Ali Amulî’nin desteklediği Murtaza ile Keyumers'in ittifak yaptığı Nasîrüddîn büyük bir savaşa tutuştular. Nasîrüddîn bir kez daha yenilmekten kurtulamadı ve Sevadkuh'a geri döndü. Bundan sonra Nasîrüddîn bir süre gurbet hayatı yaşamak mecburiyetinde kaldi. ${ }^{42}$

Nasîrüddîn'in gurbet hayatı devam ederken onun yeniden yeğeni ile mücadeleye devam etmesini sağlayan bir olay meydana geldi. Seyyid Ali Âmulî’nin Murtaza tarafindan Âmul'den çıkarıldığ 1 , onun Tenkabin'e geldiği haberini alan Nasîrüddîn, onunla bir ittifak gerçekleştirebileceği düşüncesiyle harekete geçti. Bu sırada Gilan'da bulunan Seyyid Nasîrüddîn, Karkiya Emir Seyyid Muhammed ile bir görüş alışverişi gerçekleştirdi. Bu ittifakın gerçekleşmesi halinde ailesinin emin bir yerde olması gerektiğini düşünen Nasîrüddîn, onlar1 Gerciyan'a ( كرجيان ) nakletmek üzere buranın hâkiminden özür diledi ve ona ittifak teklifinde bulundu. Bu ittifakı haber alan Murtaza, derhal ordusuyla Âmul'e geldi. Bu arada Nasîrüddîn'e yardım edenler arasında isyan edip Âmul ormanlarına sığınan Seyyid Abdülazim de bulunuyordu. İki kuvvet arasında bir kez daha meydana gelen savaşı Murtaza kazandı ve

edilen miktar ise yaklaşı 768 kg'a tekabül eder. Bu durumda vergi verilecek miktarın gerçekçi olduğunu kabul edersek üretim oldukça yüksektir. Ancak kaynaklarda belirtilen bu verginin ödediğine dair bir bilgi bulunmamaktadır. Zaten öncesinde Herat'a vaat edilen vergi sonu gelmez mücadeleler nedeniyle bozulan ekonomik durumdan dolayı verilememiştir.

${ }^{39}$ Maraşî, age, s. 272-273.

40 Emir Firuzşah, Nasirüddin'e kardeşi öldüğünde kendisi tahta geçebilecekken bunu yapmadığını ve yeğeni Murtaza'yı tahta çıkardığını söyleyerek hatasını belirtmişti. Ayrıca bununla yetinmeyip tahtı geri almak için mücadeleye giriştiğini ve Şahruh'tan yardım talebinde bulunduğunu ilave etmiştir. Ayrıca bu durumun yani Murtaza'nın tahta geçmesinin Şahruh nezdinde olumlu karşılandığını, şimdi ise kendisinin bu durumdan rahatsız olduğunu söylemiştir. Maraşî, age, s. 274.

${ }^{41}$ Maraşî, age, s. 274.

42 Age, s. 275-276; Nasirüddin, gurbet hayatında kendisine sadık kalan dervişlerden ailesinin iaşesinin temin edilmesini istemişti. Onun aile efradı Sârî'den Âmul'e göçmek zorunda kaldı. Bir kısmı ise Rüstemdar'a gitti. Zahirüddin Maraşî bu bahsi anlatırken kendisinin 5 yaşında olduğunu ve diğer kardeşinin ise 3 yaşında olduğunu belirtmektedir. Nasirüddin'in aile efradı bundan sonra sürekli yer değiştirmek suretiyle gurbet hayatı yaşamak zorunda kaldı. Maraşî’nin eserinde Rüstemdar, Gilan ve Tenkabin onların ikamet ettiği yerler olarak belirtilmiştir. Nasirüddin ise ailesinin iaşelerinin temin edilmesini sağlamak maksadiyla yerel yöneticilerden isteklerden bulunmuştur. Ailesinin himaye edilmesi karşıllğında onlara özellikle at göndererek mukabelede bulunmuştur. Maraşî, age, s. 277-278. 
Seyyid Ali Âmulî yaralı halde Nasîrüddîn ile beraber Gilan'a firar etti. Seyyid Abdülazim ise isyan halinde olduğu ormanlık alana geri döndü. ${ }^{43}$

Mâzenderân'da iç çekişmeler tüm hızıyla devam ederken öte taraftan Şahruh özelikle Karakoyunlular üzerine yaptığı seferlerde Mâzenderân Seyyidlerinden askerî yardım ve destek almaya devam ediyordu. Bu münasebetle Şahruh, Kara Yusuf ile savaş yapmak üzere hazırlık yaptığı süreçte Mâzenderân'dan savaş fili ve asker temininde bulunmuştu. Şahruh dönemi Mâzenderân'dan temin edilen askerî kuvvetin önemli görüldüğünü ve onlara savaş becerisi noktasında güvenildiğini ifade edebiliriz. Bu bağlamda daha önce olduğu gibi Karakoyunlular ile yapılan Salmas savaşında Mâzenderân askerleri Şahruh ile beraber ordunun merkezinde yer almışlardır. ${ }^{44}$ Mâzenderân'dan fil temini geleneği Karakoyunlular ile yapılan daha sonraki savaşlarda da devam etmiştir. Bu doğrultuda Eleşkirt savaşında yine Şahruh tarafından Mâzenderân'dan getirtilen filler ordunun ön saflarında kullanılmıştır. ${ }^{45} \mathrm{Bu}$ savaşların biri 823/1421, diğeri ise 832/1429 yıllarında gerçekleşmiştir. Bu arada Şahruh, 1420-1421 kışını Karabağ'da geçirdiği sırada kendisine bağlılıklarını sunmak üzere geniş katılımlı bir itaat merasimi gerçekleştirilmiştir. Bu merasime Gilan'dan Haydar Kiya ve Sârî'den Melik huzura gelenler arasindaydi. ${ }^{46}$

Kışlamak üzere çok eski zamanlardan beri göçebeler için uygun yerleşim yeri olan Hazar denizi kıyıları (çoğunlukla Mâzenderân) buraya bu maksatla gelen göçebelerin yağmalarına maruz kalmaktaydı. Şahruh, bu durumun farkındalığıyla kış mevsiminde bölgede bir veya birden fazla tecrübeli Timurlu yöneticilerin bulunmasını sağlıyordu. Hatta kışlamak üzere bazen bizzat kendisi Mâzenderân'a gidiyordu. Amacı bölgenin güvenliği sağlamak olan Şahruh'un bu konuda hassas davranmasının ne kadar yerinde olduğunu Özbeklerin saldırısından anlamak mümkündür. Özbekler, Deşt-i Kıpçak'tan Mâzenderân'a saldırmış, o sırada Mâzenderân'da kışlamak üzere bulunan Timurlu beyleri bozguna uğrayarak kaçmak zorunda kalmışlardı. ${ }^{47}$

Bu arada Safer 824/ Şubat 1421'de Nasîrüddîn, sulh yapmak üzere Âmul'e doğru yola koyulmuş, bundan bir süre sonra Ramazan 825/Ağustos 1422'de Seyyid Ali Âmulî de 50 kadar süvarisi ile Âmul'e gitmek üzere harekete geçmişti. Âmulî ile Nasîrüddîn'in şehre girişi eş zamanlı gerçekleşince onların bir kez daha ittifak yaptıkları düşüncesi hâsıl oldu. Şehirde meydana gelen çatışmada Âmulî yaralandı ve aynı yılda vefat etti. Seyyid Nasîrüddîn bir süre Âmul kalesine sığındıysa da kaleden çıkmak zorunda kaldı ve daha sonra bir etkinlik gösteremedi. Şevval 836/ Mayıs 1433'de vefat etti. ${ }^{48}$

Maraşîlerin kendi iç çekişmelerinin yanı sıra Gilan Seyyidleri ile de münasebete girdiğini ilave edelim. Cemaziyelevvel 829/ Mart 1426'da Gilan Seyyidleri tahtında meydana gelen değişiklik ile Seyyid Hüseyin Kiya, Gilan'da seyyidlerin yeni lideri oldu. 830/1427'de ise Melik Keyumers, sınır anlaşmazlığı dolayısıyla Gilan Seyyidleri ile bir mücadele içine girdi. Melik Keyumers'in Tenkabin'de yaptığı bir takım faaliyetlere karşı Gilan Seyyidleri Rüstemdâr'a saldırmadan önce Keyumers'e bir uyarıda bulundular. Ancak Keyumers' in onlara karşı düşmancıl politikalarının devam etmesi nedeniyle 831/1428'de Gilan Seyyidleri, Keyumers'in idare merkezi Rüstemdâr'a büyük bir taarruz gerçekleştirdiler. Bu saldırıda

${ }^{43}$ Age, s. 280-281.

${ }^{44}$ Hasan-1 Rumlu, Ahsenü 't-Tevarih, Çev: Mürsel Öztürk, TTK Yayınları, Ankara 2006, s. 122-125; Sümer, age, c. I, s. 106-129.

${ }^{45}$ Aka, age, s. 124.

${ }^{46}$ Age, s. 120.

${ }^{47}$ Hasan-1 Rumlu, Ahsenü 't-Tevarih, s. 239; Aka, age, s. 147-160.

${ }^{48}$ Maraşî, age, s. 282-283. 
Keyumers oldukça zor durumda kaldı. 832/1429 senesinde Keyumers'in saldırılarına karşı1ık Sârî hâkimi Murtaza ile Gilan seyyidlerinin müşterek hareket ettiğini görmekteyiz. Gilan Seyyidleri ve Maraşîler arasında Keyumers'e karşı kurulan ittifak başarı ile netice verdi ve Keyumers büyük bir mağlubiyete uğradı. ${ }^{49}$

\section{Seyyid Muhammed Dönemi Maraşîler}

Safer 837/ Eylül 1434'de Murtaza vefat edince yerine Seyyid Muhammed tahta çıkarıldı. Maraşîlerin kurucusu Seyyid Kıvamüddin'in oğlu Rızaüddin'in soyundan gelenler Sârî'de Maraşîler adına idareyi ellerinde tutmaktaydılar. Aynı zamanda bu sırada Rızaüddin'in bakiyeleri Âmul yönetiminin de sorumluluğunu uhdelerinde bulundurmaktaydılar. Seyyidlere, Sârî'de Seyyid Muhammed, Âmul'de ise oğlu Seyyid Abdülkerim liderlik yapmaktaydı. ${ }^{50}$ Anlaşıldığı kadarıyla Maraşîler, Mâzenderân'da Sârî şehrini merkez olarak kullanmaktaydılar. Bu dönemde Âmul'u, bölgenin ikinci önemli merkezi olarak zikretmek mümkündür.

Murtaza döneminde Gilan Seyyidleri ile münasebetin bu dönemde de devam ettiğini ifade edebiliriz. Gilan için anti parantez şunları belirtmek gerekir; Gilan, Maraşîlerin kendi iç çekişmelerinde kaybeden tarafın sığındığ 1 ve zaman zaman yardım aldığg bir bölgeydi. Bu bağlamdan o sırada Gilan'da bulunan Seyyid Kemalüddin'in bakiyelerinin, Âmul üzerinde Gilan Seyyidleri aracılığıyla bir girişimde bulunmasının önüne geçmek maksadıyla Seyyid Muhammed tarafindan onlara bir mektup yolland. $\mathrm{Bu}$ mektupta büyük dedeleri Kıvamüddin'in yaptığı taksimat hatıllatılarak, Kemalüddin'in bakiyelerinin zorla kendilerinden Âmul'u aldıkları, kendilerinin yani Rızaüddin taraftarlarının ise Sârî’ye giderek buna karşı çıkmadıkları ifade edilmektedir. Bu sebeple şimdi haklarını geri aldıklarını ileri sürerek Gilan Seyyidlerinin ve onların himayesinde olan Seyyid Kemalüddin taraftarlarının bu duruma razı olmaları istenmekteydi. ${ }^{51}$ Seyyid Rızaüddin taraftarlarının Gilan hükümdarına uyarı niteliğindeki bu mektubundan açıkça yönetimde söz sahibi olması gereken kitlenin kendileri olduğunun dile getirildiğini görmekteyiz. Bu açıdan Gilan'ın Mâzenderân iç işlerine müdahale etmemesi yönünde ikaz edildiğini ilave edebiliriz.

Öte taraftan Şahruh'un Azerbaycan'a yaptığı bir başka seferde Mâzenderân yerel hanedanlarından ve merkezden atanan yöneticilerden daha önce olduğu gibi istifade etmeye devam etmiştir. Bu doğrultuda Şahruh, III. Azerbaycan seferi dolayısıyla kışlamak maksatlı Rey şehrinde ikamet ettiği sırada (838/1435 y1lı k1şı) Mâzenderân'dan Emir Murtaza'nın torunu Abdülkerim ve Rüstemdar meliki Keyumers, Şahruh'un ordusuna katılmışt1. ${ }^{52}$

$\mathrm{Bu}$ gelişmelerden sonra çalışmamızın biricik kaynağının müellifi Zahirüddin Maraşî’nin de olaylar müdahil olduğunu görmekteyiz. O babası Nasîrüddîn'in izinden giderek çeşitli ittifak girişimleriyle Âmul'u ele geçirmeye çalş̧acaktır. Dedesi Seyyid Kemalüddin ile aynı adı taşıyan onun torunu Seyyid Kemalüddin, o sırada Gilan'da bulunmaktaydı. Hemen Zahirüddin Maraşî ve Gilan Seyyidleri lideri Nasîrüddîn'in babası Seyyid Abdülvahhab ile bir ittifak yapma girişiminde bulundu. Ancak Seyyid Abdülvahhab, böylesi bir mücadele için yaşlı olduğunu ileri sürerek teklifi reddetti. Bu arada Âmul'den mütemadiyen Seyyid Kemalüddin'i destekleyen mektuplar gelmekteydi. Maraş̂̂’nin belirttiğine göre Âmul'de Seyyid

\footnotetext{
${ }^{49}$ Age, s. 284-286.

${ }^{50}$ Age, s. 290; Ahsenü't-Tevarih'te 1433 yılı olayları anlatılırken Murtaza'nın vefatı sonrası Şahruh'un, Seyyid Muhammed'e ilgi ve şefkat göstererek Mâzenderân tahtına çıkardığı ifade edilmektedir. Hasan-1 Rumlu, age, s. 205.

${ }^{51}$ Age, s. 290.

${ }^{52}$ Hasan-1 Rumlu, age, s. 211-212; Aka, age, s. 151.
} 
Kemalüddin'e desteğin artması sonucu Seyyid Abdülkerim şehri terk ederek Sârî’ye gitmek zorunda kalmıştır. ${ }^{53}$

Seyyid Kemalüddin'e desteğin sadece Âmul ile sınırlı kalmadığını, Sârî dervişlerinin de ona desteklerini mektuplar ile ilettiğini Zahirüddin Marașî ifade etmektedir. Bu bağlamda onun haklılığını ortaya koyan mektuplar, hem Zahirüddin Maraşî’ye hem de Melik Keyumers'e gönderilmekteydi. Bütün bunlar yaşanırken Seyyid Kemalüddin, Gilan lideri Seyyid Nasîrüddîn Kiya'nın karşı koymasına rağmen Âmul şehrine gitti. Bu arada onun Sârî'deki destekçileri de Âmul'e geldiler. Bu olay, Âmul ve Sârî seyyidleri, yani Seyyid Kemalüddin ile Seyyid Rızaüddin'in bakiyeleri arasında yeni bir savaşın patlak vermesine neden oldu. ${ }^{54}$

Toplamda üç kez vuku bulan savaşın ilk ikisini Seyyid Kemalüddin kazanırken, son savaşı Seyyid Muhammed kazand. Bu savaşlara Esterâbâd'da bulunan Timurlu emiri Hinduke ve Padüspanî lideri Melik Keyumers de iştirak ettiler. Melik Keyumes'in girişimleri sonucu seyyidler arasında barış gerçekleşti. Ancak Zahirüddin Maraşî, bu barışın şartları veya içeriği hususunda bir bilgi vermemektedir. Bir süre sonra Âmul'de Seyyid Kemâlüddin yönetimi uhdesine almayı başarmıştır. Fakat bu defa Melik Keyumers'in Sârî seyyidlerinden yana tavır alması neticesinde Seyyid Kemalüddin Âmul'u terk etmek zorunda kalmıştır. Seyyid Kemalüddin, bu mücadelelerde kısmî bir başarı elde etmekle beraber daimi bir hâkimiyet kuramayarak 849/1445'de vefat etti. ${ }^{55}$ Seyyid Kemalüddin'in ölüm yılı, aşağı yukarı Şahruh'un ölüm yılına yakın bir dönemde gerçekleşmiştir. Bu sebeple bundan sonra Zahirüddin Maraşî de anlatılan bilgiler onun oğlu Mirza Baysungur dönemi ile alakalıdır.

\section{SONUÇ}

Şahruh dönemi Mâzenderân Seyyidlerinin siyasal yaşamına baktığımızda karşımıza çıkan ilk olgu; karmaşık bir siyasî düzlemde iç çekişmelerin yaşandığ 1 ve buna paralel bir kısır döngü içinde zaman zaman civar yerel hanedanların da kavgalara iştirak ettiğidir. Timurlu emirleri ve Pâdüspânî lideri Melik Keyumers'in Mâzenderân siyasî olaylarına müdahil olduklarını ve onların menfaatleri doğrultusunda bazen Âmul, bazen de Sârî Seyyidlerinden yana tavır aldıklarını belirtebiliriz.

Timur 1392'de Maraşilerle savaşarak seyyidlerin büyük bir kısmını sürgüne göndermiş, daha sonra 1397 'de Seyyid Kemalüddin'in oğlu Seyyid Ali'ye Âmul şehrini vererek seyyidlerin bir kısmının Mâzenderân'a geri dönmesini sağlamıştı. Timur'un ölümüyle ondan ricacı olan sürgündeki seyyidler, bu arzularına muvaffak olarak Mâzenderân'a dönmeyi başarmıştı. Seyyid Rızaüddin'in soyundan gelen bu seyyidlerin bölgeye gelişi kırk yılı aşkın sürecek olan iktidar kavgasının da fitilini ateşlemişti. Bu çerçevede, Bir tarafta Seyyid Kemalüddin'in, diğer tarafta ise Seyyid Rızaüddin'in bakiyeleri uzun y1llar sürecek iktidar kavgasına tutuştular.

Eski çağlardan beri yerel hanedanların yönettiği bölge, oldukça karmaşık bir yapıya sahipti. Bölgenin bu hususiyeti belki de Şahruh döneminde en yoğun şekilde yaşandı. Seyyidlerin amansız mücadelesine Rüstemdar melikleri, civar şehirlerdeki Timurlu valileri ve hatta Şahruh müdahil oldular. Seyyidlerle beraber eş zamanlı olarak Mirzaların veya Timurlu şehzadelerinin Mâzenderân'da idareci olduklarını belirtmek gerekir. Seyyidler ile bu Timurlu yöneticiler arasındaki münasebetin ne boyutta olduğu muğlaktır.

\footnotetext{
${ }^{53}$ Maraşî, age, s. 291-292.

${ }^{54}$ Age, s. 292.

${ }^{55}$ Age, s. 293-302.
} 
Seyyidler, Mâzenderân'a geri döndükleri 1406'dan itibaren 1421'ye kadar geçen süreçte sürekli olarak iç çekişmeler ve iktidar kavgalarıyla enerjilerini kendilerine dönük sarf ettiler. Şahruh, onların bu tavrına genel olarak kayıtsız kaldı. Bu bağlamda Şahruh'un seyyidlere tavrının oldukça ilginç olduğunu ifade edebiliriz. Zira iki kez kendi vekili hüviyetinde olan devlet görevlilerinin maruz kaldığı duruma -ki ilkinde Sârî'deki Timurlu valisinin dervişler tarafından öldürülmesi, ikincisinde ise Şahruh'un elçisinin diplomatik kaideler dişında kabul edilmesi ve aşağılanmasına- neredeyse hiç tepki göstermemiş ya da bu hususta isteksiz davranmıştır. $\mathrm{Bu}$ durumun nedeni, seyyidlere babasından kalma bir saygı geleneği çerçevesinde davranmasından kaynaklanabileceği gibi Timurlu coğrafyasında yaşanan iç sorunların merkezden uzakta olan ve ikincil derecede önemli olan bir mesele olarak görülmesiyle ifade edilebilir. Ancak seyyidlerin iç çekişmeleri ziyadeleştikçe güçleri bir o kadar azalmış, buna paralel Şahruh'un Mâzenderân'ın iç işlerine müdahil olmasına olanak sağlanmıştır. Hatta bu iç çekişmeler öyle bir noktaya ulaşmıştır ki seyyidler ağaç gövdesine düşen kurt misali önlenemez bir şekilde çöküş yaşamıştır. Özellikle Murtaza ve Nasîrüddîn'in mücadelesinde vergi verme vaadiyle her iki tarafın da Şahruh'un desteğini kazanmaya çalışması, Timurluların seyyidlerin egemenliği üzerinden bölgeye daha fazla müdahil olmalarını sağlamıştır.

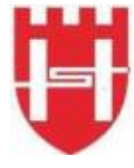

JHS

81

History Studies

Volume 8 Issue 2

June

2016

Bununla beraber Mâzenderân'da seyyidlerin kavgalarına Şahruh'un müdahale edememesinin nedeni, babasının birkaç parçaya ayırdığı Timurlu topraklarını kendi hâkimiyeti altına almaya çalışması ve enerjisini bu yönde sarf etmesiydi. Şahruh her ne kadar Mâzenderân'a atadığı mirzalara karşı sert politikalar izlediyse de seyyidlere aynı sertlikte müdahalede bulunmuyordu. Hanedan mensupları ya da hanedan mensubu olmayan yerel yöneticilere karşı tavrı oldukça sertti. Hükümdarlığ 1 döneminde çeşitli zorluklarla mücadele etmek ve çoğunlukla hâkimiyetini diğer hanedan mensuplarına kabul ettirmeye çalışmak ile geçiren Şahruh, devletine ancak 1420'li yıllardan sonra büyük oranda hâkim olmayı başarmıştı. Bu tarihler aynı zamanda Mâzenderân'daki seyyidlerin iç çekişmelerinin zirve yaptığı dönemlerdi. Murtaza ve Nasîrüddîn'in iktidar çekişmesinde vergi kozunu ileri sürerek Şahruh'tan destek almaya çalışmaları ile Seyyidlerden de vergi alınmaya başlanılmıştı. Vergi tabiiyetin esas rükunlarından biri olduğuna göre Mâzenderân'da Şahruh dönemi hâkimiyetin güçlü manada kurulabilmesi ancak 1422 'den sonra gerçekleşebilmişti. Şahruh, Seyyidlerin dâhili mücadelelerinden vergi ve asker temini hususunda istifade etmeyi başarmıştı.

1422'den sonra Şahruh'un ölümüne kadar geçen süreçte ne Timurlu kaynaklarında ne de çalışmamızın biricik kaynağı olan Zahirüddin Maraşî’nin Tarih-i Taberistan Rûyan ve Mâzenderân adlı eserinde Şahruh'un bölgeye müdahale etmesi ile ilgili bilgi bulunmamaktadır. Ancak Âmul ve Sârî'de Seyyidlerin mücadelesi 1422'den sonra da devam etmiş, hatta Şahruh'un ölümünden sonra da hız kesmemiştir. Son olarak vurgulanması gereken husus; Seyyidlerin bölgede oldukça fazla teveccüh görüyor olmasına Şahruh'un da saygı göstermesi ve dervişlerin bu dönemde lider seçiminde seyyidler üzerinde oldukça fazla etkin olmasidir. 


\section{KAYNAKÇA}

AKA, İsmail, Mirza Şahruh ve Zamanı, TTK Yayınları, Ankara 1994.

APAK, Adem, Anahatlariyla İslam Tarihi, c. IV, Ensar Yayınları, İstanbul 2012.

BORZGER, Erdeşir, Tarih-i Taberistan, Tsh: Muhammed Şükrî Fûmeşî, Neşr-i Resaneş, Tahran 1388.

CÜVEYNÎ, Alaaddin Ata Melik, Tarih-i Cihangüşa, c. II, Çev: Mürsel Öztürk, Kültür Bakanlığı Yayınları, Ankara 1988.

FAZLULLAH, Reşidüddin, Camiü't-Tevarih Selçuklu Devleti, Çev: Erkan GöksüHüseyin Güneş, Selenge Yayınları, İstanbul 2010.

HAKİKAT, Abdurrafi, Tarih-i Conbiş-i Serbedaran ve Diger Conbişha-yi Iraniyan der Kurun-u Heştom Hicri, İntişarat-1 İlmi, Tahran 1363.

HASAN-I RUMLU, Ahsenü't-Tevarih, Çev: Mürsel Öztürk, TTK Yayınları, Ankara 2006.

HINZ, Walther, İslam'da Ölçü Sistemleri, Çev: Acar Sevim, Edebiyat Fakültesi Yayınları, İstanbul 1990.

İBN İSFENDIYAR, Bahaüddin Muhammed b. Hasan, History of Tabaristan, c. II, Çev: Edward G. Browne, Leiden 1905.

İBN İSFENDIYYAR, Bahaüddin Muhammed b. Hasan, Tarih-i Taberistan, c. I, Tsh: Abbas İkbal, Tahran 1386.

İBNÜ'L-ESIR, el-Kamil fi't-Tarih Tercümesi, Çev: Ahmet Ağırakça vd., c. VI, Hikmet Neşriyat, İstanbul 2008.

KURT, Hasan, Türk-İslam Dönemine Geçişte Tahiroğulları, Araştırma Yayınları, Ankara 2002.

LE STRANGE, Guy, Serzemin-i Hilafet-i Şarkî, Çev: Mahmud İrfan, Şirket-i İntişarat-1 İlm-u Ferheng, Tahran 1377.

MANZ, Beatrice Forbez, Timurlu Iran'ında İktidar, Siyaset ve Din, Çev: Dilek Şendil, Türkiye İş Bankası Kültür Yayınları, İstanbul 2013.

MARAŞÎ, Seyyid Zahirüddin b. Seyyid Nasîrüddîn, Tarih-i Taberistan Rûyan ve Mâzenderân, Tsh: Muhammed Hüseyin Tesbihi, Müessese-i Matbuat-i Şarki, Tahran 1345 .

MEHCURİ, İsmail Tarih-i Mâzenderân, c. I, İntişarat-1 Tus, Tahran 1380.

MÜSTEVFÎ, Hamdullah, Tarih-i Güzide, Tsh: Abdü’l-Hüseyin Nevâ̂, Emir Kebir, Tahran 1364.

ÖZGÜDENLİ, Osman Gazi, “Taberistan”, TDVİA, c. XXXIX, İstanbul 2010.

PURGARİ, Salih, "Nigahi be Coğrafya-yi Tarih-i Taberistan der Kurun-u Evvel-i Hicri", ez-Zehra Üniversitesi İnsani Illimler Araştırma ve Illim Dergisi, S. XVII-XVIII, 1380, s. 33-56.

RENÇBER, Akif, "İslam Fethinden Irak Selçuklularının Yıkılışına Kadar Kazvin'in Siyasî Tarihi”, Insan ve Toplum Bilimleri Araştırmaları Dergisi, c. I, S. I, 2012. 
RENÇBER, Akif, Mâzenderân (Taberistan) Tarihi 1220-1392, (Furat Üniversitesi Sosyal Bilimler Enstitüsü, Yayınlanmamış Doktora Tezi), Elazığ 2015.

RÜSTEMİ, Mustafa, Hüner-i Tabarestan, İntişarat-i Müessese-i Amuzeş Alî-yi Marlik, Babilsor 1392hş.

SAMEDÎ, Hüseyin, Ketabnâme-i Mâzenderân, c. I, Sazman-ı Bername-i Ostan-ı Mâzenderân, Sârî 1372.

SEMERKANDÎ, Kemaleddin Abdurrezzak, Matlaü'Sadeyn ve Mecmaü'l-Bahreyn, c. III, Pejuheşgahî Ulum-u İnsanî ve Mütalaat-1 Ferhengî, Tahran 2004.

SPULER, Bertold, Iran Moğolları, Çev: Cemal Köprülü, TTK Yayınları, Ankara 2011.

SÜMER, Faruk, Karakoyunlular, c. I, TTK Yayınları, Ankara 1992.

ŞAMİ, Nizamüddin, Zafername, Çev: Necati Lugal, TTK Yayınları, Ankara 1987.

TACÜ'S-SELMANÎ, Tarihname, Çev: İsmail Aka, TTK Yayınları, Ankara 1999.

YILMAZ, Saim, Mutazıd ve Müktefi Döneminde Abbasiler, Kayıhan Yayınları, İstanbul 2006. 